\title{
Winter bat activity in the Canadian prairies
}

\author{
C.L. Lausen and R.M.R. Barclay
}

\begin{abstract}
Periodic arousal from hibernation among mammalian hibernators is poorly understood. In bats, arousal is often associated with flight. We acoustically monitored two rocky areas along the Red Deer River in southeastern Alberta for bat activity in autumn, winter, and spring months. We found bats to be active in all months and at unexpectedly cold temperatures (coldest activity $-8{ }^{\circ} \mathrm{C}$ ). Bats were active even when ambient temperatures remained below $0{ }^{\circ} \mathrm{C}$ during the day and night. We documented Myotis ciliolabrum (Merriam, 1886), Myotis evotis (H. Allen, 1864), and Eptesicus fuscus (Beauvois, 1796) flying outside hibernacula in winter. Active E. fuscus that we captured in mid-winter of 2004-2005 weighed less than bats captured in the fall, but masses ranged from 14.0 to $21.0 \mathrm{~g}$, indicating that some individuals still had fat reserves. Captured individuals were of various ages, with a male bias. Using radiotelemetry, we located the first natural rock-crevice hibernacula for male and female E. fuscus in the Canadian prairies. Winter roosts were narrow, deep rock crevices or erosion holes located in steep valley walls. We found evidence to suggest that dehydration may be a driving force for winter flights.
\end{abstract}

Résumé : L'éveil périodique durant l'hibernation chez les mammifères hibernants reste mal compris. Chez les chauvessouris, l'éveil est souvent associé au vol. Nous avons suivi par des méthodes acoustiques l'activité des chauves-souris dans deux régions rocheuses le long de la Red Deer dans le sud-est de l'Alberta durant les mois de l'automne, de l'hiver et du printemps. Nous trouvons des chauves-souris actives à tous les mois et à des températures étonnamment froides $\left(-8^{\circ} \mathrm{C}\right.$, température d'activité la plus basse). Les chauves-souris sont actives même lorsque les températures ambiantes restent sous $0^{\circ} \mathrm{C}$ durant le jour et la nuit. Nous avons observé Myotis ciliolabrum (Merriam, 1886), Myotis evotis (H. Allen, 1864) et Eptesicus fuscus (Beauvois, 1796) en train de voler hors de leur hibernacle en hiver. Les E. fuscus capturés au milieu de l'hiver 2004-2005 sont moins lourds que ceux capturés à l'automne, mais leur masse varie de 14,0 à 21,0 g, ce qui indique que certains individus ont encore des réserves lipidiques. Les individus capturés appartiennent à différentes classes d'âge et il y a une majorité de mâles. À l'aide de la radiotélémétrie, nous avons trouvé les premiers hibernacles naturels dans des crevasses rocheuses pour les mâles et les femelles d'E. fuscus dans les prairies canadiennes. Les perchoirs d'hiver consistent en des crevasses rocheuses étroites et profondes ou en des trous d'érosion situés dans des parois escarpées des vallées. Nous avons des indications qui laissent croire que la déshydratation peut être le motif qui explique les vols d'hiver.

[Traduit par la Rédaction]

\section{Introduction}

All mammalian hibernators arouse periodically throughout the winter (Kayser 1965; Willis 1982). Bouts of winter torpor are days or weeks in length (Willis 1982), and $>80 \%$ of fat depletion in hibernation can be due to arousals (Kayser 1965; Thomas et al. 1990). The function of these energetically expensive arousals is not well understood and numerous physiological hypotheses have been proposed, including water intake for ionic balance and circulatory functioning (Speakman and Racey 1989; Thomas 1995; Thomas and Geiser 1997), to sleep (Trachsel et al. 1991), maintenance of neural circuitry (Popov et al. 1992), lymphocyte regeneration (Burton and Reichman 1999), and more (reviewed in Humphries et al. 2003). While most mammalian hibernators are relatively dormant during these periods of arousal (Willis 1982), some animals, such as bats, are active, spend-

Received 20 December 2005. Accepted 13 June 2006. Published on the NRC Research Press Web site at http://cjz.nrc.ca on 1 September 2006.

C.L. Lausen ${ }^{\mathbf{1 , 2}}$ and R.M.R. Barclay. Department of Biological Sciences, University of Calgary, Calgary, AB T2N 1N4, Canada.

${ }^{1}$ Corresponding author (e-mail: corilausen@netidea.com).

${ }^{2}$ Present address: Box 920, Kaslo, BC V0G 1M0, Canada. ing additional energy to move around or leave the hibernaculum.

As small flying insectivorous hibernators, non-migratory bats face unique thermoregulatory challenges in temperate zones. Unable to hoard food, bats are fat-storing hibernators, with energy-reserve sizes limited by their small body size and by their need to fly. Bats have evolved to successfully overwinter in areas such as the Canadian prairies where winters can be harsh; temperatures can reach less than $-45^{\circ} \mathrm{C}$ and insect abundance is low or non-existant for more than 150 days each year. Winter arousal and activity of bats is well documented for warmer temperate climates: in southern Ontario, where some bats hibernate in buildings (Brigham 1987); in Poland (Krzanowski 1959), southern England (Avery 1985; Park et al. 1999), Minnesota (Swanson and Evans 1936), and Nevada (O'Farrell and Bradley 1970), where bats reportedly arouse and forage during winter months; and in Germany (Sendor et al. 2000) and Indiana (Whitaker and Rissler 1992), where emergence has been documented without evidence of foraging. In more harsh temperate climates, such as the Canadian prairies, winter flights of bats are not expected because of a lack of insects, although arousals within roosts may occur for physiological reasons.

Several hypotheses have been proposed to explain why 
bats may be active during hibernal arousals: to feed (Willis 1982; Avery 1985), to drink (Thomas and Geiser 1997), or to change hibernation sites (Daan 1973; Sendor et al. 2000). Feeding has been observed during some winter bat flights (e.g., Avery 1985); however, diminishing energy as a possible reason for arousal and winter bat flight has received less support than the importance of water (Speakman and Racey 1989; Hays et al. 1992; Whitaker and Rissler 1992; Thomas 1995; Thomas and Geiser 1997).

Where most bats hibernate in Alberta is not known. A few cave hibernacula in the Rocky Mountains have been found, but they account for relatively small numbers of bats (<1000; Schowalter 1980). Stimulated by late-summer captures in Dinosaur Provincial Park, Alberta (Schowalter and Allen 1981), we monitored this prairie riparian area in late November 2002, during a Chinook (a warm, dry wind that occasionally blows down the east slopes of the Rocky Mountains), to determine if bats were overwintering in the river valley. We detected winter bat flights. Given that temperatures earlier that month reached a low of $-12{ }^{\circ} \mathrm{C}$ (Environment Canada 2005a), hibernation should have begun and we concluded that bat activity at this time of year was indicative of hibernal arousal. As this was the first non-building bat hibernation area identified in the Canadian prairies, we monitored the park and another area of similar terrain. We hypothesized that bats use rock crevices in the river valley as hibernacula and arouse during warm Chinook periods when temperatures exceed $0{ }^{\circ} \mathrm{C}$. Our goals were to determine what species were hibernating in the park, at what temperatures bats were flying, what the sex and body condition was of the individuals, and to find natural prairie hibernacula.

\section{Materials and methods}

We acoustically monitored two main locations along the Red Deer River in Alberta: Dinosaur Provincial Park (DPP; $50^{\circ} 45^{\prime} 23^{\prime \prime} \mathrm{N}, 111^{\circ} 31^{\prime} 02^{\prime \prime} \mathrm{W}$ ) and East Coulee (EC; $\left.51^{\circ} 19^{\prime} 58^{\prime \prime} \mathrm{N}, 112^{\circ} 28^{\prime} 49^{\prime \prime} \mathrm{W}\right)$. Both areas consist of badland terrain rich in sandstone rock crevices and solidified mud erosion holes, with DPP being a larger area (badland features extend $>5 \mathrm{~km}$ from the river) than EC. EC has many abandoned coal mines. Bat species captured or acoustically detected here in the summer months are as follows: Eptesicus fuscus (Beauvois, 1796), Myotis lucifugus (LeConte, 1831), Myotis ciliolabrum (Merriam, 1886), Myotis evotis (H. Allen, 1864), Lasionycteris noctivagans (LeConte, 1831), Lasiurus cinereus (Beauvois, 1796), and Lasiurus borealis (Müller, 1776). This part of Alberta is arid, averaging $<350 \mathrm{~mm}$ of precipitation per year, with temperature extremes ranging from greater than $40{ }^{\circ} \mathrm{C}$ in the summer (July average daily maximum $26{ }^{\circ} \mathrm{C}$ ) to less than $-45{ }^{\circ} \mathrm{C}$ in the winter (January average daily minimum $-17{ }^{\circ} \mathrm{C}$ ); mean number of days with maximum and minimum temperatures $\leq 0{ }^{\circ} \mathrm{C}$ are 77.8 and 194.8, respectively (Environment Canada 1997-2000).

Preliminary data were collected from DPP in 2002-2004. Additionally, we opportunistically monitored Writing on Stone Provincial Park campground on the Milk River $\left(49^{\circ} 03^{\prime} 25^{\prime \prime} \mathrm{N}, 111^{\circ} 37^{\prime} 28^{\prime \prime} \mathrm{W}\right)$ in 2002-2003. This arid rocky riparian area features hoodoos, i.e., eroded pillars of sand- stone. Our main data collection took place in 2004-2005 at DPP and EC.

We used remote acoustic zero-crossing analysis to detect and identify bats (Corben 2002). These detection systems consisted of an AnaBat detector (Titley Electronics, Ballina, New South Wales, Australia) with a tape recorder in 20022003 and with a compact flash ZCA interface module (CF ZCAIM; Titley Electronics) for all subsequent work. We powered the system with an external battery charged by a solar panel. We monitored DPP and EC continuously during the winter of 2004-2005, beginning on 16 October 2004. Data were collected until 17 June and 4 May 2005 for EC and DPP, respectively. Previous to this, in 2002-2003, and limited by the tape-recording system, we monitored opportunistically in late fall and early spring, and in the winter only during warm Chinook winds, at DPP and at Writing on Stone Provincial Park.

We digitized call sequences from tapes using AnaBat version 6.0 (Corben 2004) and visualized all calls (from tape and CF ZCAIM) using AnaLook version 4.9j (Corben 2004). Eptesicus fuscus calls (minimum frequency $\left(f_{\min }\right)<$ $30 \mathrm{kHz})$ were identified visually and Myotis calls $\left(f_{\min }>\right.$ $30 \mathrm{kHz}$ ) were analyzed further for species identification. Although E. fuscus calls are similar to the calls of L. noctivagans, this latter species migrates south out of the province during the winter (Smith 1993); therefore, all $\sim 25 \mathrm{kHz}$ winter passes were assumed to be that of E. fuscus. We followed the same procedure as used by Wilson (2004), and manually selected complete search-phase calls (maximum frequency $\left(f_{\max }\right) \geq 60 \mathrm{kHz}$ ), analyzed these using AnaLook, and identified the species using discriminant function analyses (see below).

We captured bats in DPP along the Little Sandhill Creek, a small tributary draining into the Red Deer River, using mist nets on the following winter/spring nights: 30 March 2004; 23 and 24 April 2004; 3, 11, and 23 February 2005; and 1, 4, 5, 9 March 2005. We also captured bats periodically in the summer and fall months in DPP from 2002 to 2004. Each bat was weighed and sexed. We recorded degree of toothwear (from a scale of 1-7, where 1 is reserved for the sharp teeth of juveniles; Holroyd 1993), measured forearm length using calipers, and applied a plastic split-ring band for future identification. Each bat was kept for $1 \mathrm{~h}$ to check for feces. During winter 2004-2005, in all but the first capture, we also offered water to each bat. All animals were cared for in accordance with the principles and guidelines of the Canadian Council on Animal Care and appropriate animal care permits were obtained.

In February 2005, we attached $0.5 \mathrm{~g}$ radio transmitters (Holohil Systems, Ltd., Woodlawn, Ontario) to three E. fuscus (two males and one female) that we captured in DPP and tracked them to their rock-crevice hibernacula. We accessed roosts using ropes, measured outside dimensions, and where possible roost depth. To assess whether insect prey were available to flying bats from 3 February to 9 March 2005, we erected a suction insect trap $1.5 \mathrm{~m}$ above ground each night that we netted $(n=13)$. We operated the trap for the duration of the netting sessions.

We recorded ambient temperature $\left(T_{\mathrm{a}} ; \pm 0.7{ }^{\circ} \mathrm{C}\right)$ using two HOBO Loggers ${ }^{\circledR}$ (Onset Computer Corporation, Pocasset, Massachusetts), encased in solar radiation shields, placed at 
our two main study sites. Temperature readings were taken every $15 \mathrm{~min}$ to $1 \mathrm{~h}$, depending on the site and time of year. If a bat pass occurred between two temperature readings and the $T_{\mathrm{a}}$ at the start of the interval was warmer than at the end, the $T_{\mathrm{a}}$ at the start of the interval was used to provide a conservative estimate of flight $T_{\mathrm{a}}$; otherwise, $T_{\mathrm{a}}$ was interpolated assuming a linear pattern.

The insect trap, AnaBat, and temperature dataloggers were all located in the netting area, on a creek tributary $<1 \mathrm{~km}$ from the Red Deer River. Nets were strung along the meandering Little Sandhill Creek, in an area where the hoodoo features create a narrow $(\sim 200 \mathrm{~m})$ bottleneck in the creek valley. To the north of the netting area lies a large flat flood zone and the Red Deer River; to the south the creek, surrounded by badland features, extends $>5 \mathrm{~km}$, where it originates as meltwater and runoff from the surrounding higher elevation grasslands.

We performed statistical analyses using SAS $^{\circledR}$ version 9.1 (SAS Institute Inc. 2002-2003) and Stata ${ }^{\circledR}$ version 9 (StataCorp LP 2006). We performed direct discriminant function analysis (Proc DISCRIM) on echolocation call parameters $\left(f_{\min }\right.$, mean frequency, characteristic slope, and $\left(f_{\max }-f_{\min }\right) /$ duration) extracted using AnaLook. Myotis calls (i.e., those with $f_{\min }>30 \mathrm{kHz}$ ) that were of sufficient quality to analyze, were classified as $M$. ciliolabrum, $M$. evotis, or M. lucifugus. Quadratic discriminant function analysis was performed (Tabachnick and Fidell 2001), using reference calls from locally captured $M$. ciliolabrum $(n=64)$, M. evotis $(n=26)$, and M. lucifugus $(n=168)$. We recorded reference calls using an AnaBat and audio tape recorder; all $M$. ciliolabrum and $M$. evotis were recorded after hand-release, while the majority of (148) M. lucifugus call sequences were of free-flying individuals outside known roosts. Overall cross-validation error was 0.085 (range $0.078-0.100$ ), and only passes that could be identified to species with $\geq 95 \%$ probability were accepted. Mass of captured bats was compared using analyses of covariance (ANCOVA), with season of capture and forearm length as the dependent variable and covariate, respectively. All values are means $\pm \mathrm{SE}$.

\section{Results}

\section{Acoustic detection}

We carried out noncontinuous acoustic recording at DPP during 2002 and 2004, and first detected winter bat activity on 19 November 2002, when maximum daytime and minimum nighttime temperatures were 14 and $2.4{ }^{\circ} \mathrm{C}$, respectively. During this Chinook period, we detected E. fuscus and M. ciliolabrum. We detected E. fuscus on 7 March 2004, the first day that year that the detector was out in the field. Myotis spp. were first detected on 11 March 2004 and discriminant function analyses of Myotis spp. detected between 11 and 31 March 2004 revealed that both M. ciliolabrum and $M$. evotis were present. We did not detect M. lucifugus. No winter bat activity was detected at Writing on Stone Provincial Park.

Beginning on 16 October and 26 September 2004, we recorded continuously at DPP and EC, respectively, and detected E. fuscus and Myotis spp. activity throughout November and part of December (Fig. 1). In total, we re- corded 535 passes at DPP and 65 passes at EC in November, and 377 passes at DPP and 71 passes at EC in December. The last Myotis bat pass in 2004 at both DPP and EC was on 18 December, when maximum daytime and minimum nighttime temperatures were 2.9 and $-7.3{ }^{\circ} \mathrm{C}$, respectively, at DPP and -1.5 and $-5.8{ }^{\circ} \mathrm{C}$, respectively, at EC. The last E. fuscus pass was on 24 December at EC and 25 December at DPP, when maximum daytime and minimum nighttime temperatures were -1.1 and $-12.0{ }^{\circ} \mathrm{C}$, respectively, and -1.5 and $-18.1{ }^{\circ} \mathrm{C}$, respectively. The longest period during which no bat was detected was 23 days (25 December - 18 January) at EC and 22 days (26 December 16 January) at DPP (Fig. 1). During this time $T_{\mathrm{a}}$ reached $-46{ }^{\circ} \mathrm{C}$. After this cold period, E. fuscus and Myotis spp. were again active starting on 18 January and 2 February, respectively, at EC, and 17 and 30 January, respectively, at DPP. At both locations, during the winter of 2004-2005 (21 December 2004 - 21 March 2005), 43 of 67 Myotis spp. passes were analyzable, and of these, 23 could be identified to species with $\geq 95 \%$ probability. All passes were of $M$. ciliolabrum and $M$. evotis, with the exception of one $M$. lucifugus pass detected at DPP on 6 March 2005. Myotis lucifugus was not detected again until 3 April 2005.

We detected bats on nights when the temperature at the time of emergence (defined as civil twilight, when the sun is $6^{\circ}$ below the horizon) was below $0{ }^{\circ} \mathrm{C}$ (Myotis spp.: 6 nights at EC and 12 nights at DPP; E. fuscus: 17 nights at EC and 20 nights at DPP). Myotis spp. and E. fuscus were not detected on nights when emergence temperatures were colder than $-5.8{ }^{\circ} \mathrm{C}(n=43)$ or $-5.3{ }^{\circ} \mathrm{C}(n=46)$, respectively. We detected bats flying on nights when daytime $T_{\mathrm{a}} \mathrm{s}$ had not gone above freezing (Myotis spp.: 1 night each at EC and DPP; E. fuscus: 8 nights at EC and 4 nights at DPP). The coldest $T_{\mathrm{a}} \mathrm{s}$ at which E. fuscus and Myotis spp. passes occurred were -7.9 and $-6.3{ }^{\circ} \mathrm{C}$, respectively. Monitoring that was repeated in the winter of 2005-2006 revealed the coldest passes at -7.9 and $-7.3{ }^{\circ} \mathrm{C}$, respectively (C.L. Lausen, unpublished data). On nights when temperatures remained above these temperature limits, bat activity occurred throughout the night. During Chinook periods, warmest temperatures did not always occur early in the evening, and peak bat activity could not be predicted; when temperatures warmed prior to sunrise, bat activity was detected at dawn, including one E. fuscus detected 19 min after sunrise. Strong winds associated with Chinook periods may make bat flight difficult, and this could explain why $T_{\mathrm{a}}$ was not always a good predictor of bat activity (Fig. 2).

\section{Bat captures}

We captured E. fuscus opportunistically at DPP in 2003 2005 (Table 1). The majority of captures (95\% of 184) were male. The testes of the majority of males ( $84 \%$ of 134 ) captured in July were scrotal. Bats captured in winter included both young and old individuals, as indicated by the degree of tooth wear (Table 1).

Of the nine E. fuscus captured in the winter of 2004 2005, four bats had an earthy smell, suggesting that they may have been roosting in contact with moist soil. No feces were produced by these winter captures. The mean mass of male and female E. fuscus captured in the winter of 2004- 
Fig. 1. Number of bat passes per night and associated temperatures for Dinosaur Provincial Park, 16 October - 6 March 2005. The upper temperature (broken) line is the temperature at which light levels would have been typical of bat emergence and the lower temperature (solid) line is the minimum nighttime temperature. Open bars indicate E. fuscus passes and solid bars indicate Myotis spp. passes.

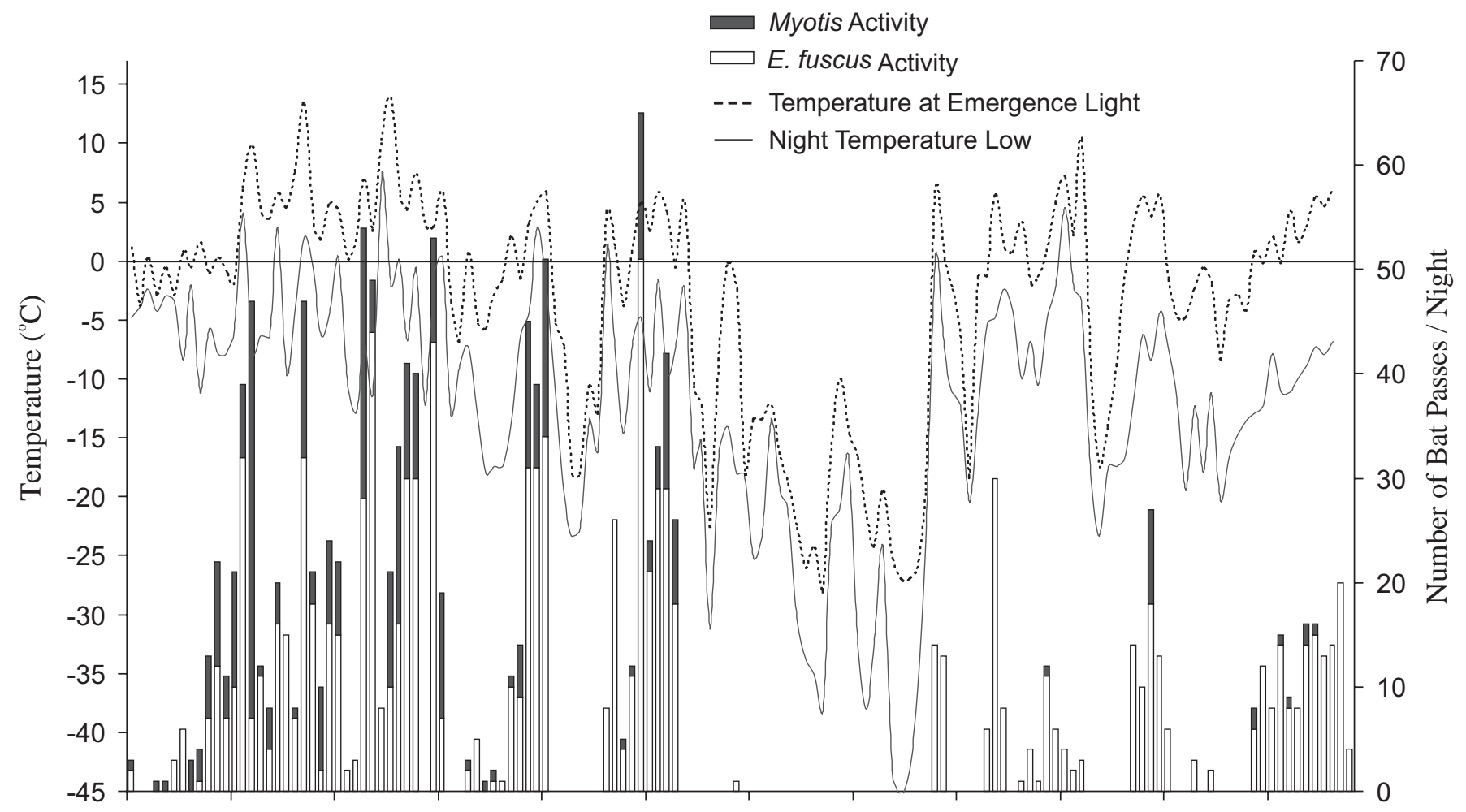

16-Oct. 28-Oct. 9-Nov. 21-Nov. 3-Dec. 15-Dec. 27-Dec. 8-Jan. 20-Jan. 1-Feb. 13-Feb. 25-Feb.

Date (2004-2005)

Fig. 2. Number of bat passes per night versus temperature at emergence light levels for Dinosaur Provincial Park, 16 October -20 March 2005.

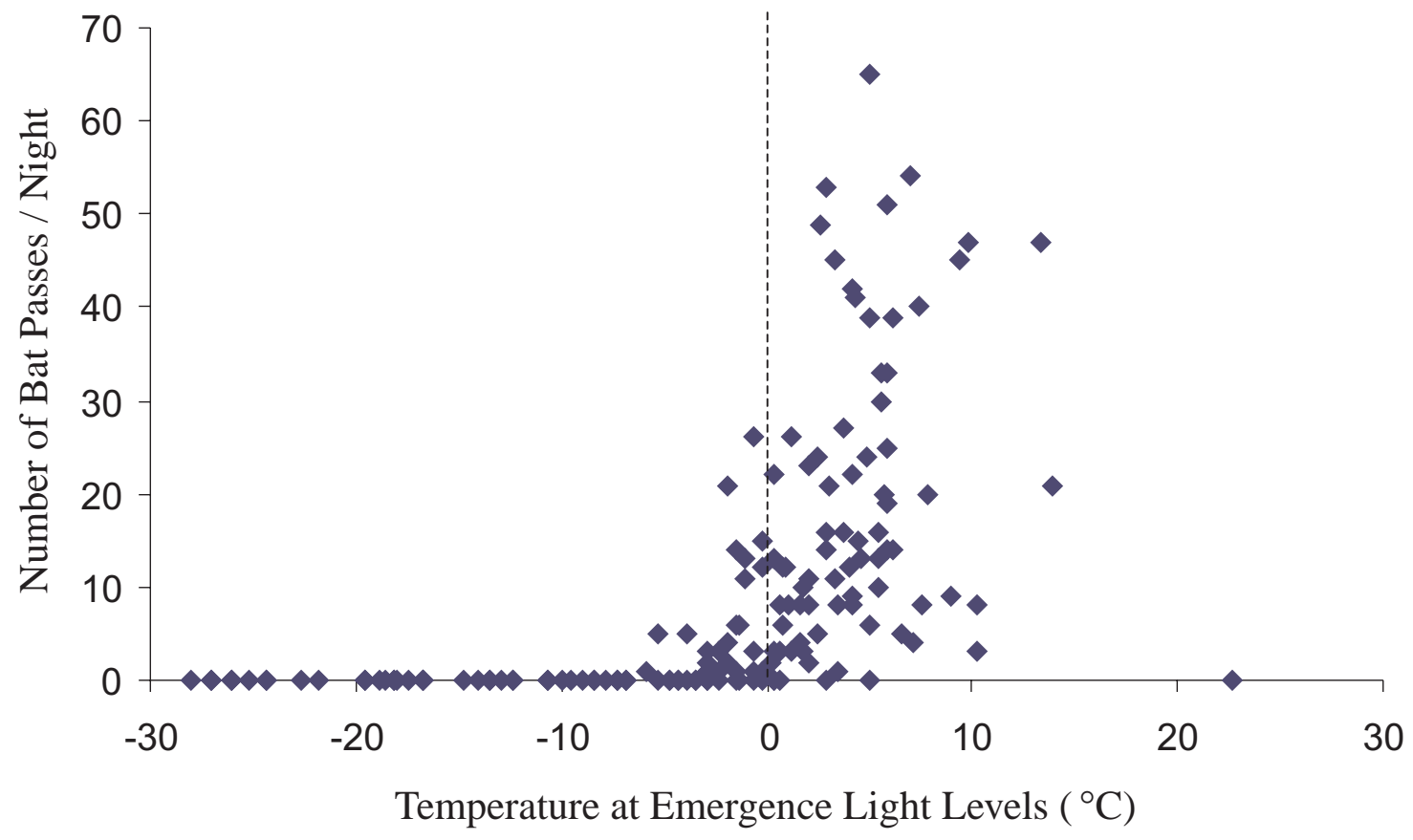


Table 1. Mass (mean \pm SE) and forearm (mean \pm SE) measurements of Eptesicus fuscus captures at Dinosaur Provincial Park from 2003 to 2005 .

\begin{tabular}{|c|c|c|c|c|c|c|c|c|}
\hline Year & Dates & \multicolumn{2}{|c|}{ Number of captures } & $\begin{array}{l}\text { Range of tooth } \\
\text { class }(1-7)\end{array}$ & \multicolumn{2}{|l|}{ Mass and range $(\mathrm{g})$} & \multicolumn{2}{|c|}{ Forearm length $(\mathrm{mm})$} \\
\hline 2004 & 30 Mar., 23 Apr. & 2 & 1 & $2-5$ & $17.2 \pm 1.3(15.9-18.5)$ & 15.2 & $46.3 \pm 3.2$ & 47.7 \\
\hline 2004 & $10,24,27$ June & 18 & 1 & $2-7$ & $16.2 \pm 0.5(12.6-20.9)$ & 15.9 & $46.2 \pm 0.4$ & 48.5 \\
\hline 2004 & $13-15,18$ July & 87 & 9 & $2-7$ & $17.9 \pm 0.2(14.6-20.8)$ & $20.8 \pm 0.4(19.3-23.2)$ & $46.2 \pm 0.2$ & $48.3 \pm 0.4$ \\
\hline
\end{tabular}

Note: Pregnant females and individuals not held for at least $1 \mathrm{~h}$ prior to weighing are not included in the mean mass. na, not available.

$2005(16.5 \pm 0.6 \mathrm{~g}, n=9)$ was significantly less than the mean mass of adult bats in autumn 2003 and $2004(21.3 \pm$ $\left.0.8 \mathrm{~g}, n=12 ; F_{[1,14]}=10.96, p=0.005\right)$, but not significantly different than $E$. fuscus in spring $2004(16.5 \pm 1.0 \mathrm{~g}$, $n=3)$ and summer 2004 (17.9 $\pm 0.18 \mathrm{~g}, n=115$; model: $F_{[4,134]}=11.5, p<0.0001$; season: $F_{[3,134]}=11.4, p<$ 0.00001 ; forearm length covariate: $F_{[1,134]}=8.5, p=0.004$; Tukey's WSD test: autumn captures differed significantly from captures in the other three seasons, which did not differ from each other).

Eight of the E. fuscus captured in the winter of 20042005 were captured on the side of the net (north-facing), suggesting that they were traveling back to hibernacula (located south of netting area - see below) from the river. We offered water from an eyedropper to seven of these bats before releasing them, but they did not drink. Four urinated in the mist net when handled. Only one bat was captured immediately at emergence moving towards the river, suggesting that it had just left its hibernaculum. This bat did not urinate in the net and was the only bat that drank water when offered; he consumed $>3 \mathrm{~mL}$ of water shortly after capture and urinated when released an hour later.

We affixed radio transmitters to two males (3 and 23 February 2005) and one female (11 February 2005) E. fuscus and tracked them to their winter roosts, up-creek from the netting area. We tracked both males to the same rock-crevice roost, approximately $200 \mathrm{~m}$ from their site of capture on Little Sandhill Creek. Although the female was also captured at this same site, we radio-tracked her to a roost $5 \mathrm{~km}$ away.

The rock crevice that the males roosted in was a crack in a boulder $10 \mathrm{~m}$ from flat ground above and $22 \mathrm{~m}$ from flat ground below. The opening had a large deposit of bat feces, was $15 \mathrm{~cm}$ high, and ranged from 1 to $2.5 \mathrm{~cm}$ wide. The roost faced southeast $\left(130^{\circ}\right.$ aspect) on a steep $\left(80^{\circ}\right)$ slope. Because of the shape of this crevice, a depth measurement was not possible. The crevice that the female roosted in was a tubular erosion hole in solidified mud, which was located 3 and $3.5 \mathrm{~m}$ to flat ground above and below, respectively. The roost was at least $3.55 \mathrm{~m}$ deep, with an oval opening of $7 \mathrm{~cm} \times 5 \mathrm{~cm}$, faced southeast $\left(168^{\circ}\right.$ aspect), and was located on a steep $\left(70^{\circ}\right)$ slope. Feces deposit at the entrance was less than at the male hibernaculum. Roosts were accessible only with ropes and were likely never disturbed by other wildlife or humans. Radio-transmitter signals did not change location for the duration of the battery life (1218 days).

\section{Insects and weather}

We caught no insect in the light-funnel trap, although we observed a total of four moths flying on the nights of 5 and 9 March 2005. A male E. fuscus captured on 5 March 2005 was kept for $1 \mathrm{~h}$ and, while he did urinate, he did not deficate, suggesting that he had drunk but did not feed. Feces were produced by the one E. fuscus captured on 30 March 2004.

During 2004-2005, the Canadian prairies experienced a winter that was, on average, $1.6{ }^{\circ} \mathrm{C}$ warmer than normal, although it was only the 27th warmest winter since 1948 (Environment Canada 2005b). We thus assume that the bat activity detected in 2004-2005 was not unusual. DPP experienced a complete snowmelt at the end of January 2005, leaving little to no snow on the ground for most of February and March; a thin layer of ice remained on the river, with small pockets of snow remaining in sheltered areas of the valley. Open water (i.e., melted creek/river water) was not abundant until the end of February.

\section{Discussion}

Little is known about hibernation of bats in the North American prairies. The results of our study provide the first records of natural hibernacula for bats in the Canadian prairie ecozone, of Myotis spp. flying during mid-winter in Canada, and of hibernating E. fuscus flying outside rock-crevice hibernacula in mid-winter. We detected bats flying at temperatures well below zero (less than or equal to $-7.9{ }^{\circ} \mathrm{C}$ ). Although bat activity below $0{ }^{\circ} \mathrm{C}$ has been noted at high altitudes in arid regions of the southwestern United States (Nevada: O'Farrell and Bradley 1970; Hall 2005; New Mexico: L. Lewis, personal communication, 2005), this is the first time that such bat activity has been recorded at low altitude and high latitude.

There is a universal occurrence of periodic arousals among hibernating mammals, but most hibernators arouse for a few hours and remain relatively inactive in their hibernacula (Willis 1982). Periodic euthermy is thought to be necessary to restore physiological balance (Willis 1982). Bats partaking in energetically expensive flight during arousal suggests that bats may be unique in their hibernation behaviour, with requirements beyond restoration of the euthermic state. Although feeding has been suggested as a reason for winter flight (Avery 1985), it was not the impetus for winter flights in our study. Insects were not active at the 
ambient temperatures experienced in this study (Taylor 1963), supported by the lack of insects in our light trap, and bats did not produce feces.

Bats captured in winter weighed less than those in the fall, but they did not differ from bats captured in summer. Although some studies have suggested that only starving individuals make winter flights in an attempt to attain food (Brigham 1987), our data suggest that not all bats active in winter have critically low energy reserves, corroborating other studies (Hays et al. 1992).

Because of the large non-furred surface area of the wing and tail membranes, bats have higher evaporative water losses than other similar-sized mammals (Webb 1995). A laboratory study of Pipistrellus pipistrellus (Schreber, 1774) indicated that bats must drink every 9-12 days during hibernation (Speakman and Racey 1989). Dehydration may be a more important arousal factor in bats than in other small fat-storing hibernators. Bats hibernating in caves experience humid environments, may lick condensation from their fur (reviewed in Speakman and Racey 1989), and have been observed drinking (reviewed in Davis 1970). The only E. fuscus that consumed water when it was offered was the bat captured on its way out of the hibernaculum immediately at emergence, and most bats caught later in the night urinated upon capture. While it is possible that bats were urinating metabolically produced water, voiding of this type of urine is typically observed in association with immediate arousal from hibernation (Kallen 1964; Davis 1970). The only bat captured on its way out of the hibernaculum did not urinate until its release $1 \mathrm{~h}$ after drinking. Our sample size is small, but suggests that bats flying in winter during this study may have been drinking; the source of water during part of the winter was not evident, given the freezing temperatures and paucity of snow in the area. Dehydration has been suggested as a factor for hibernal arousal (Thomas 1995), and we suggest that it may play a role in winter bat flight.

Relative humidity in rock-crevice roosts of arid regions is low (Lausen 2001) compared with that of cave roosts (Davis 1970), and dehydration from evaporative water loss may be an even greater problem for bats hibernating in arid climates (Kallen 1964; Thomas and Cloutier 1992), such as the Canadian prairies, Nevada, and New Mexico, where subzero winter flights have been reported. Roosting in narrow crevices that would offer few microclimate options and no water source may force bats to fly outside the hibernaculum, and at temperatures typically considered too cold for bat activity. Because our data involve small samples sizes and anecdotal accounts, we suggest that further research is necessary to determine the possible effect that dehydration has on arousal and activity of bats hibernating in arid environments.

As indicated by relative toothwear and reproductive condition, bats active in the winter were not of a particular age class, contrary to a previous study which suggested that juvenile E. fuscus are more active than adults (Brigham 1987). However, the sex ratio of our winter captures was highly skewed towards males. This may accurately reflect the number of males and females that are active in winter, if males hibernating in DPP outnumber females. However, the male bias could also be an artifact caused by sampling <200 m from the rock crevice where two males were tracked and $5 \mathrm{~km}$ from the roost used by the female. This assumes that there is sexual segregation within the hibernation area, something that has been documented elsewhere for E. fuscus (Mills et al. 1975).

Winter flight activity seems to vary with bat species and location (O'Farrell and Bradley 1970; Whitaker and Rissler 1992). Eptesicus fuscus is described as a hardy species that is often found roosting in cold, dry conditions (Davis 1970) and whose winter activity has been observed previously (Rysgaard 1942; Brigham 1987). Because the frequency of arousals increases with body mass (French 1988), the larger size of E. fuscus compared with that of M. evotis and M. ciliolabrum may explain why we detected more winter flights of $E$. fuscus. However, the location of hibernacula of the different species relative to where we placed the detectors could also produce this skew. The fact that Myotis spp. were detected at all suggests that the need for winter flight is common among species in our study area.

We detected only one winter flight of M. lucifugus, a species that tends to cluster in large groups (Kurta and Baker 1990) and one that roosts in high humidity hibernacula (reviewed in Fenton and Barclay 1980). It is possible that this species does not hibernate in large numbers in the rockcrevice area of DPP, despite roosting there in the summer. Alternatively, its acoustic absence during most of the winter might reflect less frequent winter flights; evaporative water loss may be lower because of clustering (Studier 1970), thereby reducing the need for winter flight (Daan 1973).

Where most E. fuscus hibernate is largely unknown (e.g., Mills et al. 1975). Although some hibernate in buildings (Whitaker and Gummer 2000), few natural E. fuscus hibernacula have been identified (Kurta and Baker 1990). Indeed, it has been hypothesized that, because E. fuscus is absent or rare in most cave hibernacula, the hibernaculum of choice for this species has historically been trees - roosts that would not be insulative enough in cold northern areas (Whitaker and Gummer 2000). Whitaker and Gummer (2000) thus proposed that heated buildings have provided this species with non-tree hibernacula, allowing it to expand northward. Our data indicate that hibernation by E. fuscus in northern areas is possible without buildings, because of their use of small rock-crevice hibernacula (this study; Neubaum 2004) that are difficult to detect. Thus, we suggest that the historic geographic range of E. fuscus was greater than hypothesized by Whitaker and Gummer (2000) and that E. fuscus did not move northwards in response to human-made roosts.

Because climate directly influences hibernating mammals (Humphries et al. 2001), global climate change is likely to influence bat populations overwintering in the Canadian prairies. Since 1948, average yearly temperatures in Canada have increasingly been above normal (using 1951-1980 as the baseline; Environment Canada 2006). If the Canadian prairie climate continues to become drier with climate change, as predicted by Environment Canada (1997), bats hibernating in rock crevices may be burdened with additional evaporative water loss brought about by decreased humidity and increased temperatures (Kallen 1964). One response may be more frequent arousal and winter flights, placing greater strain on stored fat reserves. In the Canadian prairies, where higher altitude refugia are not available, distributional ranges may shift (Humphries et al. 2002). Estab- 
lishing baseline data for species composition of bats in prairie hibernation areas, including frequency of winter flights, will allow for ongoing monitoring to determine if changing prairie climate is altering distribution and abundance of bats (Humphries et al. 2003).

\section{Acknowledgements}

We thank the staff at Dinosaur Provincial Park, especially P. Hofer, R. Hugill, and M. Macdonald, for logistical support; Alberta Sport, Parks, Recreation, and Wildlife Foundation for funding; and B. Moffet at Writing on Stone Provincial Park, and K. Patriquin and M. Proctor for field assistance. This work was funded in part by a grant from the Natural Sciences and Engineering Research Council of Canada (NSERC) to R.M.R.B. and by scholarships / research allowances from NSERC, Alberta Ingenuity, and Killam Trust to C.L.L.

\section{References}

Avery, M.I. 1985. Winter activity of pipistrelle bats. J. Anim. Ecol. 54: 721-738.

Brigham, R.M. 1987. The significance of winter activity by the big brown bat (Eptesicus fuscus): the influence of energy reserves. Can. J. Zool. 65: 1240-1242.

Burton, R.S., and Reichman, O.J. 1999. Does immune challenge affect torpor duration? Funct. Ecol. 13: 232-237. doi:10.1046/j. 1365-2435.1999.00302.x

Corben, C. 2002. Zero-crossings analysis for bat identification: an overview. In Bat echolocation research: tools, techniques and analysis. Edited by R.M. Brigham, E.K.V. Kalko, G. Jones, S. Parsons, and H.J.G.A. Limpens. Bat Conservation International, Austin, Tex. pp. 95-107.

Corben, C. 2004. AnaBat (version 6.0) and AnaLook (version 4.9j) [computer programs]. Available from http://www.hoarybat.com [accessed 15 February 2006].

Daan, S. 1973. Activity during natural hibernation in 3 species of Vespertilionidae bats. Neth. J. Zool. 23: 1-71.

Davis, W.H. 1970. Hibernation: ecology and physiological ecology. In Biology of bats. Edited by W.A. Wimsatt. Academic Press, New York. pp. 265-300.

Environment Canada. 1997. The Canada country study: climate impacts and adaptation - Canadian Prairies summary. Environment Canada, Ottawa, Ontario.

Environment Canada. 1997-2000. Climate normals and averages. Available from http://www.climate.weatheroffice.ec.gc.ca/ climate_normals [accessed 16 April 2005].

Environment Canada. 2005a. National climate archive. Available from http://www.climate.weatheroffice.ec.gc.ca [accessed 16 April 2005].

Environment Canada. 2005b. The green lane. Available from http:// www.ec.gc.ca/envhome.html [accessed 16 April 2005].

Environment Canada. 2006. The green lane. Available from http:// www.ec.gc.ca/envhome.html [accessed 24 August 2006].

Fenton, M.B., and Barclay, R.M.R. 1980. Myotis lucifugus. Mamm. Species, 142: 1-8.

French, A.R. 1988. The patterns of mammalian hibernation. Am. Sci. 76: 569-575.

Hall, D. 2005. Novel techniques to improve long-term monitoring of bats in the Nevada test site, south-central Nevada. In Proceedings of the Western Bat Working Group Biennial Conference, Portland, Oregon, 30 March - 2 April 2005. Western Bat Working Group, Rapid City, S. Dak.
Hays, G.C., Speakman, J.R., and Webb, P.I. 1992. Why do brown long-eared bats (Plecotus auritus) fly in winter? Physiol. Zool. 65: $554-565$.

Holroyd, S.L. 1993. Influences of some extrinsic and intrinsic factors on reproduction by big brown bats (Eptesicus fuscus) in southeastern Alberta. M.Sc. thesis, Department of Biological Sciences, The University of Calgary, Calgary, Alta.

Humphries, M.M., Thomas, D.W., and Kramer, D.L. 2001. Torpor and digestion in food-storing hibernators. Physiol. Biochem. Zool. 74: 283-292. doi:10.1086/319659. PMID:11247747.

Humphries, M.M., Thomas, D.W., and Speakman, J.R. 2002. Climate-mediated energetic constraints on the distribution of hibernating mammals. Nature (London), 418: 313-316. doi:10. 1038/nature00828. PMID:12124621.

Humphries, M.M., Thomas, D.W., and Kramer, D.L. 2003. The role of energy availability in mammalian hibernation: a costbenefit approach. Physiol. Biochem. Zool. 76: 165-179. doi:10. 1086/367950. PMID:12794670.

Kallen, F.C. 1964. Some aspects of water balance in hibernating bats. Ann. Acad. Sci. Fenn. Ser. A IV Biol. 71: 257-268.

Kayser, C. 1965. Hibernation. In Physiological mammalogy. II. Mammalian reactions to stressful environments. Edited by $\mathrm{W}$. Mayer and R. van Gelder. Academic Press, New York. pp. 179-296.

Krzanowski, A. 1959. Some major aspects of population turnover in wintering bats in the cave at Pulawy (Poland). Acta Theriol. 3: $27-43$.

Kurta, A., and Baker, R.H. 1990. Eptesicus fuscus. Mamm. Species, 356: 1-10.

Lausen, C.L. 2001. Thermoregulation and roost selection by reproductive big brown bats (Eptesicus fuscus) roosting in the South Saskatchewan River Valley, Alberta: rock-roosting and buildingroosting colonies. M.Sc. thesis, Department of Biology, University of Calgary, Calgary, Alta.

Mills, R.S., Barrett, G.W., and Farrell, M.P. 1975. Population dynamics of the big brown bat (Eptesicus fuscus) in southwestern Ohio. J. Mammal. 56: 591-604.

Neubaum, D. 2004. Preliminary findings on winter roost selection by big brown bats (Eptesicus fuscus) along a plains-mountain interface. Bat Res. News, 45: 248.

O'Farrell, M.J., and Bradley, W.G. 1970. Activity patterns of bats over a desert spring. J. Mammal. 51: 18-26.

Park, J.K., Jones, G., and Ransome, R.D. 1999. Winter activity of a population of greater horseshoe bats (Rhinolophus ferrumequinum). J. Zool. (Lond.), 248: 419-427.

Popov, V.I., Bocharova, L.S., and Bragin, A.G. 1992. Repeated changes of dendritic morphology in the hippocampus of ground squirrels in the course of hibernation. Neuroscience, 48: 45-51. doi:10.1016/0306-4522(92)90336-Z. PMID:1584424.

Rysgaard, G.N. 1942. A study of the cave bats of Minnesota with especial reference to the large brown bat, Eptesicus fuscus fuscus (Beauvois). Am. Midl. Nat. 28: 245-267. doi:10.2307/ 2420702.

SAS Institute Inc. 2002-2003. SAS ${ }^{\circledR}$. Version 9.1 [computer program]. SAS Institute Inc., Cary, N.C.

Schowalter, D.B. 1980. Swarming, reproduction, and early hibernation of Myotis lucifugus and M. volans in Alberta, Canada. J. Mammal. 61: 347-350.

Schowalter, D.B., and Allen, A. 1981. Late summer activity of small-footed, long-eared and big brown bats in Dinosaur Park, Alberta. Blue Jay, 39: 50-53.

Sendor, T., Kugelschafter, K., and Simon, M. 2000. Seasonal variation of activity patterns at a pipistrelle (Pipistrellus pipistrellus) hibernaculum. Myotis, 38: 91-109. 
Smith, H.C. 1993. Alberta mammals: an atlas and guide. The Provincial Museum of Alberta, Edmonton.

Speakman, J.R., and Racey, P.A. 1989. Hibernal ecology of the pipistrelle bat: energy expenditure, water requirements and mass loss, implications for survival and the function of winter emergence flights. J. Anim. Ecol. 58: 797-813.

StataCorp LP. 2006. Stata ${ }^{\circledR}$. Version 9 [computer program]. StataCorp LP, College Station, Tex.

Studier, E.H. 1970. Evaporative water loss in bats. Physiol. Biochem. Zool. 35: 935-943.

Swanson, G., and Evans, C. 1936. The hibernation of certain bats in southern Minnesota. J. Mammal. 17: 39-43.

Tabachnick, B.G., and Fidell, L.S. 2001. Using multivariate statistics. 4th ed. Allyn and Bacon, Boston, Mass.

Taylor, L.R. 1963. Analysis of the effect of temperature on insects and flight. J. Anim. Ecol. 32: 99-117.

Thomas, D.W. 1995. The physiological ecology of hibernation in vespertionid bats. Symp. Zool. Soc. Lond. 67: 233-244.

Thomas, D.W., and Cloutier, D. 1992. Evaporative water loss by hibernating little brown bats, Myotis lucifugus. Physiol. Zool. 65: $443-456$.

Thomas, D.W., and Geiser, F. 1997. Periodic arousals in hibernating mammals: is evaporative water loss involved? Funct. Ecol. 11: 585-591. doi:10.1046/j.1365-2435.1997.00129.x.
Thomas, D.W., Dorais, M., and Bergerson, J.-M. 1990. Winter energy budgets and cost of arousals for hibernating little brown bats, Myotis lucifugus. J. Mammal. 71: 475-479.

Trachsel, L., Edgar, D.M., and Heller, H.C. 1991. Are ground squirrels sleep deprived during hibernation? Am. J. Physiol. 260: R1123-R1129. PMID:2058740.

Webb, P.I. 1995. The comparative ecophysiology of water balance in microchiropteran bats. Symp. Zool. Soc. Lond. 67: 203218.

Whitaker, J.O., and Gummer, S.L. 2000. Population structure and dynamics of big brown bats (Eptesicus fuscus) hibernating in buildings in Indiana. Am. Midl. Nat. 143: 389-396.

Whitaker, J.O., and Rissler, L.J. 1992. Winter activity of bats at a mine entrance in Vermillion County, Indiana. Am. Midl. Nat. 127: 52-59. doi:10.2307/2426321.

Willis, J.S. 1982. The mystery of the periodic arousal. In Hibernation and torpor in mammals and birds. Edited by C.P. Lyman, J.S. Willis, A. Malan, and L.C.W. Wang. Academic Press, New York. pp. 92-103.

Wilson, J. 2004. Foraging behaviour of insectivorous bats during an outbreak of western spruce budworm. M.Sc. thesis, Department of Biology, University of Calgary, Calgary, Alta. 